\title{
MITIGASI BANJIR DAS CITARUM HULU BERBASIS MODEL HEC-HMS
}

\section{Flood Mitigation of Upper Citarum Base on HEC-HMS Model}

\author{
Diah Listyarini ${ }^{1) *}$, Yayat Hidayat2) dan Boedi Tjahjono ${ }^{2)}$ \\ 1) Jurusan Agroekoteknologi, Fakultas Pertanian, Universitas Jambi, Jl. Lintas Jambi - Muara Bulian, Muaro \\ Jambi, Jambi \\ 2) Departemen Ilmu Tanah dan Sumberdaya Lahan, Fakultas Pertanian, Institut Pertanian Bogor, J1. Meranti \\ Kampus IPB Darmaga Bogor 16680
}

\begin{abstract}
Floods that occur almost every year in the Upper Citarum River Watershed cause these watersheds to be in the spotlight of various parties. Hydrological modeling is one of the flood mitigation techniques for predicting flood discharge in a watershed. The HEC-HMS model can be used for prediction flood discharge base for analysis of a catchment system, particularly for calculating the unmeasured rainfall-runoff. HEC-HMS consists of rainfall and catchment characteristics as input and flow discharge and runoff volume as output. The objectives of this research are: (i) to the overview performance of the HEC-HMS model to predict peak discharge in Upper Citarum Watershed; (ii) to analyst of flood discharge using simulation HEC-HMS model; (iii) to recommend flood mitigation scenario to reduce peak discharge in Upper Citarum Watershed. Primary preparation of HEC-HMS model parameter input calculated by HEC-GeoHMS with the SCS method. Flood discharge calculated in the HEC-HMS model by SCS-Unit Hydrograph method for transform component, recession method for baseflow component, and lag method for routing component. The result showed that the HEC-HMS model has good performance in predicting flood discharge with $R^{2}$ and NSE value in the calibration process by $0.81-0.96$ and 0.56-0.87. The validation process in predicting flood discharge produced $R^{2}$ and NSE value by 0.81-0.94 and 0.45-0.76 respectively. 4th scenario is best practice management that can be implemented in reduced peak discharge up to 61.96\%, to increase time to peak by 3.75 hours and reduce volume discharge up to $49.58 \%$.
\end{abstract}

Keywords: Citarum upstream, flood mitigation, HEC-HMS, peak discharge, SCS method

\begin{abstract}
ABSTRAK
Banjir yang terjadi hampir setiap tahun di DAS Citarum Hulu menyebabkan DAS ini menjadi sorotan oleh berbagai pihak. Pemodelan hidrologi merupakan salah satu teknik mitigasi banjir untuk memprediksi debit banjir di daerah aliran sungai. Model HEC-HMS dapat digunakan sebagai dasar untuk prediksi debit banjir di suatu DAS, terutama untuk menghitung hujan-runoff yang tidak terukur. Model HEC-HMS terdiri dari curah hujan dan karakteristik sebagai input serta debit aliran dan volume runoff sebagai output. Tujuan dari penelitian ini adalah: (i) untuk memprediksi debit puncak di DAS Citarum Hulu; (ii) melakukan analisis terhadap debit banjir menggunakan simulasi model HEC-HMS; dan (iii) memberi rekomendasi skenario mitigasi banjir untuk mengurangi debit puncak di DAS Citarum Hulu. Persiapan parameter utama untuk input model HECHMS dihitung dengan menggunakan extention HEC-GeoHMS dengan metode SCS. Debit banjir yang dihitung pada model HEC-HMS menggunakan metode SCS-UH pada komponen transform, metode recession pada komponen baseflow, dan metode lag pada komponen routing. Hasil analisis menunjukkan bahwa model HEC-HMS memiliki performance yang baik dalam memprediksi debit banjir dengan nilai $\mathrm{R}^{2}$ dan NSE pada proses kalibrasi berturut-turut sebesar 0.81-0.96 dan 0.56-0.87. Pada proses validasi dalam memprediksi debit banjir menghasilkan nilai $\mathrm{R}^{2}$ dan NSE masing-masing sebesar 0.81-0.94 dan 0.45-0.76. Skenario 4 merupakan skenario mitigasi banjir yang dapat diimplementasikan dalam penurunan debit banjir hingga $61.96 \%$, meningkatkan time to peak hingga 3.75 jam dan mengurangi volume debit aliran hingga $49.58 \%$.
\end{abstract}

Kata kunci: Citarum hulu, mitigasi banjir, HEC-HMS, debit puncak, metode SCS

\section{PENDAHULUAN}

Banjir merupakan salah satu fenomena hidrometeorologis yang sering terjadi di sebagian wilayah Indonesia pada musim hujan. Banjir di Daerah Aliran Sungai (DAS) Citarum Hulu merupakan salah satu kejadian banjir di Indonesia yang terjadi setiap tahun dan menimbulkan kerusakan serta kerugian yang tidak sedikit. Berdasarkan hasil kajian BPLHD (2013) banjir di DAS Citarum Hulu telah terdistribusi pada 28 kecamatan yang mencakup 79 kelurahan di sekitar Sungai Citarum. Banjir dengan periode ulang kejadian antara 2-5 tahunan saat ini mengenangi daerah seluas
2,100 ha, untuk periode ulang 10-25 tahunan meningkat menjadi 19,165 ha, sedangkan banjir dengan periode ulang di atas 25 tahun memiliki luas genangan 22,725 ha.

Kondisi tersebut disebabkan oleh meningkatnya aktivitas masyarakat yang menuntut pemanfaatan lahan untuk berbagai kepentingan dan berujung pada berkurangnya luas daerah resapan air dan terjadinya erosi di wilayah hulu serta sedimentasi pada saluran drainase dan wilayah hilir. Hal tersebut mengakibatkan menurunnya fungsi hidrologis DAS sehingga pada saat terjadi hujan maka debit aliran semakin meningkat dan melebihi kapasitas tampung sungai. Berdasarkan kompleksitas kondisi tersebut serta mengingat 
bahwa DAS Citarum Hulu tergolong sebagai DAS yang memiliki prioritas tinggi untuk diperbaiki dalam skala nasional (berdasarkan SK Kemehut nomor SK.328/Menhut-II/2009), maka diperlukan upaya-upaya mitigasi.

Salah satu yang dapat dilakukan adalah melakukan penelitian dengan pendekatan sistem DAS guna mempelajari karakteristik dan memprediksi debit aliran pada DAS melalui pemodelan hidrologi (Indarto, 2012). Dalam konteks mitigasi banjir, salah satu model hidrologi yang dapat digunakan untuk memprediksi debit banjir yang dapat digunakan adalah model HEC-HMS (Hydrologic Enggineering Center-Hydrologic Modeling System). Model HEC-HMS dikembangkan oleh United States Army Corp of Engineers untuk mensimulasikan proses hujan-debit pada suatu sistem DAS (USACE, 2012).

Pemodelan debit banjir menggunakan HEC-HMS dapat dijadikan sebuah alat untuk memonitor dan mengevaluasi debit sungai melalui pendekatan potensi aliran yang terjadi (Affandy dan Anwar, 2008; Putiamini, 2014). Tujuan dari penelitian ini adalah: (i) mengetahui performance model HECHMS melalui simulasi debit banjir DAS Citarum Hulu; (ii) melakukan analisis debit banjir dengan menggunakan model HEC-HMS (iii) menentukan skenario terbaik untuk mitigasi banjir di DAS Citarum Hulu.

\section{BAHAN DAN METODE}

Penelitian dilakukan pada bulan April 2016 hingga April 2017 di DAS Citarum Hulu yang terletak pada

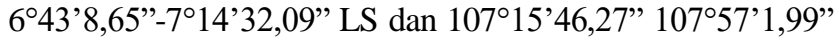
BT yang dibatasi oleh outlet Nanjung. Wilayah DAS Citarum Hulu memiliki luas sebesar 175,008.33 ha. Secara geografis DAS Citarum Hulu dibatasi oleh Kabupaten Subang dan Purwakarta dibagian utara; Kabupaten Cianjur dan Garut dibagian selatan; Kabupaten Bandung Barat dibagian timur; Kabupaten Sumedang dan Garut dibagian barat.

Bahan yang digunakan pada penelitian ini yaitu data skunder yang terdiri dari: debit aliran sungai dan data curah hujan tahun 2013-2014. Beberapa jenis peta yang digunakan pada penelitian ini yaitu: Peta Penggunaan lahan tahun 2013 dan 2014 skala 1:50,000, Peta Jenis Tanah skala 1:100,000 dan Peta RBI skala 1:25,000. Peralatan yang digunakan pada penelitian ini yaitu: (i) seperangkat komputer yang dilengkapi dengan perangkat lunak ArcGIS 10.2, HEC-GeoHMS 10.2, HEC-HMS 4.2; (ii) Global Position System (GPS); (iii) ring sampler dan alat-alat lainnya yang dipergunakan dalam pengambilan sampel tanah dan analisis di laboratorium.

\section{Prosedur Penelitian}

\section{Delineasi Batas DAS}

Delineasi batas DAS dilakukan dengan menggunakan data DEM yang disusun berdasarkan data ketinggian pada Peta RBI. Proses delineasi batas DAS dilakukan dengan software AcrGIS dengan extention HECGeoHMS. Proses delineasi didahului dengan melakukan beberapa analisis terrain processing yang terdiri dari: DEM reconditioning, fill sink, flow direction, flow accumulation, stream definition, stream segmentation, catchment grid delineation, drainage line processing, adjoint catchment dan processing. Proses selanjutnya input posisi outlet untuk melakukan delineasi otomatis dan menghasilkan satu wilayah
DAS beserta komponen hidrologinya (sub-DAS, reach, junction dan sink).

\section{Parameterisasi Model HEC-HMS}

Langka awal dalam parameterisasi model HECHMS adalah melakukan pengumpulan data skunder serta pengambilan dan analisis sampel tanah untuk input data tanah sebagai data karakteristik DAS pada Model HEC-HMS. Penyusunan parameterisasi model HEC-HMS dilakukan pada extention HEC-GeoHMS yang dijalankan pada software ArcGIS. Tahap ini terbagi menjadi empat komponen yaitu: komponen loss, transform, baseflow dan routing. Komponen loss pada penelitian ini dihitung dengan menggunakan metode SCS Curve Number dengan menggunakan tiga parameter yaitu: initial abstraction (Ia), bilangan kurva aliran (curve number) dan lapisan kedap air (impervious).

Parameter utama yang digunakan dalam perhitungan komponen transform adalah waktu tenggang (time lag) yang dihitung dengan metode SCS Unit Hydrograph. Komponen baseflow menggambarkan proses aliran dasar yang terjadi pada saat terjadinya limpasan. Metode baseflow pada penelitian menggunakan metode recession, parameter yang diperlukan yaitu: debit awal (initial discharge), konstanta resesi (recession constant) dan ratio to peak. Komponen routing menggambarkan analisis matematik yang berujuan untuk melacak aliran melalui sistem hidrologi (Sitanggang et al., 2014). Metode routing yang digunakan pada penelitian ini menggunakan metode Lag yang dihitung dengan persamaan Kirpich (1940).

Data curah hujan di input dalam model meteorologi dengan menggunakan metode Specified Hyetograph menggunakan data curah hujan yang lebih spesifik pada masing-masing sub DAS. Pada penelitian ini kondisi aktual DAS Citarum Hulu mewakili kejadian banjir tanggal 8 Januari 2013.

\section{Kalibrasi dan Validasi Model}

Keberhasilan penerapan model hidrologi pada suatu DAS tergantung pada seberapa baik kalibrasi model dan bergantung pada kemampuan teknis model hidrologi serta kualitas data yang diinput pada model tersebut (Choudhari et al., 2014). Kalibrasi model bertujuan untuk memperoleh hidrograf hasil hitungan model sama atau menyerupai hidrograf terukur. Proses kalibrasi dilakukan dengan menentukan nilai-nilai parameter dari karakteristik DAS sebagai input model agar sesuai dengan kondisi lapang. Metode statistik yang digunakan pada proses kalibrasi adalah koefisien determinasi $\left(\mathrm{R}^{2}\right)$ dan Nash Sutcliffe Efficiency (NSE) yang dihitung menggunakan persamaan:

$$
\begin{gathered}
\mathrm{R}^{2}=\left(\frac{\sum_{\mathrm{i}=1}^{\mathrm{n}}\left(\mathrm{Q}_{o b s, \mathrm{i}}-\overline{\mathrm{Q}}_{\mathrm{obs}, \mathrm{i}}\right) \sum_{\mathrm{i}=1}^{\mathrm{n}}\left(\mathrm{Q}_{\mathrm{mod}, \mathrm{i}}-\overline{\mathrm{Q}}_{\mathrm{mod}, \mathrm{i}}\right)}{\sqrt{\sum_{\mathrm{i}=1}^{\mathrm{n}}\left(\mathrm{Q}_{\mathrm{obs}, \mathrm{i}}-\overline{\mathrm{Q}}_{\mathrm{obs}, \mathrm{i}}\right)^{2} \sum_{\mathrm{i}=1}^{\mathrm{n}}\left(\mathrm{Q}_{\text {mod }, \mathrm{i}}-\overline{\mathrm{Q}}_{\mathrm{mod}, \mathrm{i}}\right)^{2}}}\right)^{2} \\
\mathrm{NSE}=1-\left[\frac{\sum_{i=1}^{n}\left(Q_{m o d, i}-Q_{o b s, i}\right)^{2}}{\sum_{i=1}^{n}\left(Q_{o b s, i}-\bar{Q}_{o b s, i}\right)^{2}}\right]
\end{gathered}
$$

Keterangan: $\mathrm{Q}_{\text {obs }}$ adalah parameter model hasil pengukuran lapang $\left(\mathrm{m}^{3}\right.$ detik $\left.{ }^{-1}\right)$, $\mathrm{Q}_{\text {mod }}$ adalah parameter model hasil simulasi model $\left(\mathrm{m}^{3} \operatorname{detik}^{-1}\right), \bar{Q}_{\text {obs }}$ adalah parameter model 
hasil pengukuran lapang rata-rata $\left(\mathrm{m}^{3} \operatorname{detik}^{-1}\right)$, dan $\bar{Q}_{\text {mod }}$ adalah parameter model hasil simulasi model rata-rata $\left(\mathrm{m}^{3}\right.$ $\left.\operatorname{detik}^{-1}\right)$. Tingkat keandalan model pada penelitian ini berdasarkan koefisien Nash-Sutcliffe ditentukan berdasarkan tingkat performance yang selengkapnya disajikan pada Tabel 1. Validasi model dilakukan dengan memastikan bahwa model tersebut cocok digunakan pada perhitungan periode ulang banjir selanjutnya.

\section{Simulasi Skenario Mitigasi Banjir}

Skenario mitigasi banjir yang digunakan pada penelitian ini antara lain: (i) penggunaan lahan berdasarkan pola ruang pada Rencana Tata Ruang Provinsi (RTRWP) Jawa Barat Tahun 2005-2025; (ii) Penerapan Rencana Teknik Rehabilitasi Hutan dan Lahan Daerah Aliran Sungai (RTkRHL DAS) Wilayah Balai Pengelolaan DAS CitarumCiliwung tahun 2015-2029; (iii) Penggunaan lahan dengan menerapkan sistem pengendalian aliran in situ (gabungan RTkRHL dan optimasi fungsi kawasan resapan air berdasarkan arahan RTRWP Jawa Barat) dan; (iv) Penerapan semua skenario mitigasi banjir (skenario 1, 2, dan 3) secara bersamaan.

\section{HASIL DAN PEMBAHASAN}

\section{Deliniasi Batas DAS Citarum Hulu}

Tahap awal simulasi model adalah delianiasi batas DAS menggunakan model HEC-GeoHMS berdasarkan nilai threshold dari flow accumulation. Gokgoz et al., (2006) perbedaan nilai threshold menghasilkan panjang dan kualitas drainage lines pada deliniasi batas DAS. Oleh karena itu pada proses deliniasi batas DAS harus memperhatikan nilai threshold sehingga jumlah dan batas sub DAS yang dihasilkan sesuai dengan kondisi di lapangan. Nilai threshold yang digunakan pada penelitian ini adalah $206.5 \mathrm{~km}^{2}$. Hasil proses delineasi batas DAS menggunakan extention HEC-GeoHMS yang dijalankan pada ArcGIS 10.2 secara otomatis menghasilkan lima sub DAS yang mewakili wilayah penelitian yaitu: sub DAS Ciwidey (W60), Cisangkuy (W70), CitarikCikeruh (W80), Cikapundung (W90) dan Cirasea (W100), selengkapnya disajikan pada Gambar 1.

Tabel 1. Kelas Performance model berdasarkan Koefisien NashSutcliffe.

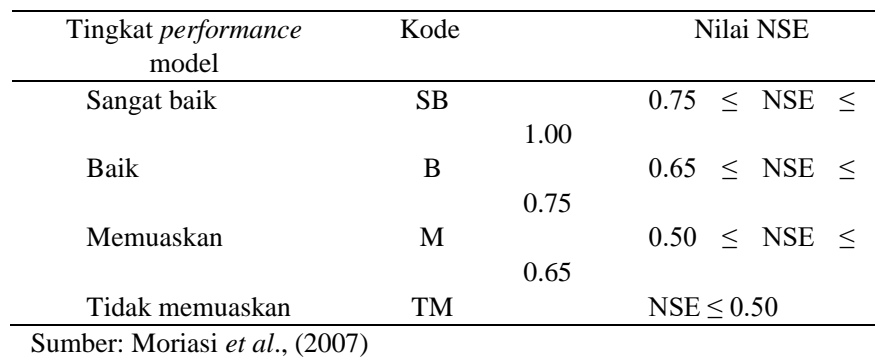

\section{Kalibrasi dan Validasi Model HEC-HMS}

Kalibrasi pada penelitian ini menggunakan metode trial dan error. Parameter sensitif pada proses kalibrasi pada penelitian ini mengacu pada USACE (2012) yaitu: initial abstraction (Ia), bilangan kurva aliran (CN), lag time, recession constant, ratio to peak dan lag. Nilai kalibrasi dan model HEC-HMS selengkapnya disajikan pada Tabel 2.

Kalibrasi selanjutnya dilakukan dengan membanding nilai debit hasil simulasi model dengan debit hasil hasil pengukuran dilapangan pada 10 kejadian banjir pada tahun 2013. Berdasarkan nilai parameter hasil kalibrasi diperoleh nilai koefisien determinasi $\left(\mathrm{R}^{2}\right)$ dan nilai koefisien NSE berturut-turut sebesar 0.81-0.96 dan 0.56-0.87. Hidrograf banjir pada proses kalibrasi disajikan pada Gambar 2.

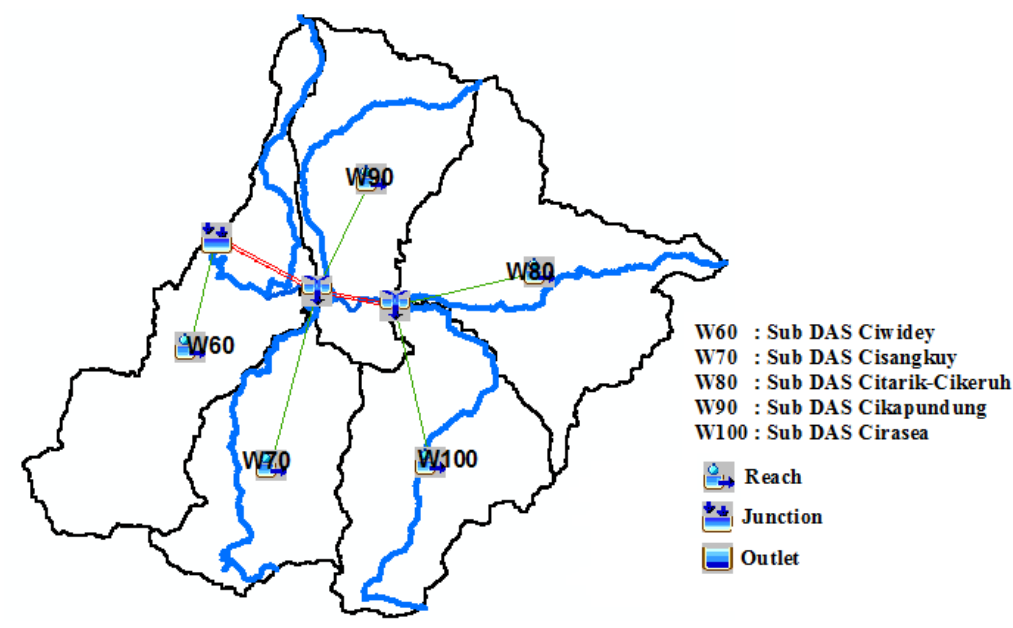

Gambar 1. Hasil delineasi batas DAS Citarum Hulu

Tabel 2. Parameter input model yang digunakan pada model HEC-HMS

\begin{tabular}{clcrrr}
\hline No. & \multicolumn{1}{c}{ Parameter } & Unit & Minimum & Maksimum & Nilai yang digunakan \\
\hline 1 & Initial abstraction & $\mathrm{mm}$ & 0.00 & 500.00 & $8.65-16.99$ \\
2 & Curve number & - & 25.00 & 99.00 & $59.00-98.00$ \\
3 & Lag & Jam & 0.10 & 500.00 & $2.47-3.76$ \\
4 & Recession constant & - & 0.00001 & - & 0.73 \\
5 & Ratio to peak & - & 0.00 & 1.00 & 0.59
\end{tabular}


$6 \quad$ Lag

Validasi model pada penelitian ini menggunakan data tahun 2014 yaitu: data penggunaan lahan, data curah hujan, dan debit observasi. Parameter yang digunakan dalam validasi ini disesuaikan dengan parameter yang digunakan saat kalibrasi model. Validasi dilakukan pada 7 kejadian banjir pada tahun 2014. Hidrograf banjir pada proses validasi disajikan pada Gambar 3.

Hasil validasi model HEC-HMS pada tahun 2014 memperoleh nilai $\mathrm{R}^{2}$ sebesar 0.81-0.93 dan nilai NSE sebesar 0.45-0.76. Nilai tersebut menunjukkan bahwa model HECHMS yang digunakan memiliki konsistensi yang baik untuk digunakan pada periode tahun selanjutnya.
0.10

500.00

$1.31-1.80$

\section{Debit Puncak (Peak Discharge)}

Hasil analisis model HEC-HMS menunjukkan bahwa debit puncak (peak discharge) pada kondisi aktual pada masing-masing sub DAS sebesar 102.10-259.56 $\mathrm{m}^{3}$ detik $^{-1}$. Sementara debit puncak di outlet Nanjung mencapai $722.44 \mathrm{~m}^{3}$ detik $^{-1}$. Berdasarkan hasil analisis debit puncak tertinggi terdapat pada sub DAS Cirasea sebesar $259.56 \mathrm{~m}^{3}$ detik $^{-1}$ dan debit puncak terkecil terdapat pada sub DAS Ciwidey sebesar $102.10 \mathrm{~m}^{3}$ detik $^{-1}$. Perbandingan debit puncak pada masing-masing beberapa skenario mitigasi banjir dengan kondisi aktual secara spasial selengkapnya disajikan pada Gambar 4.

\section{Karakteristik Hidrologi DAS Citarum Hulu}

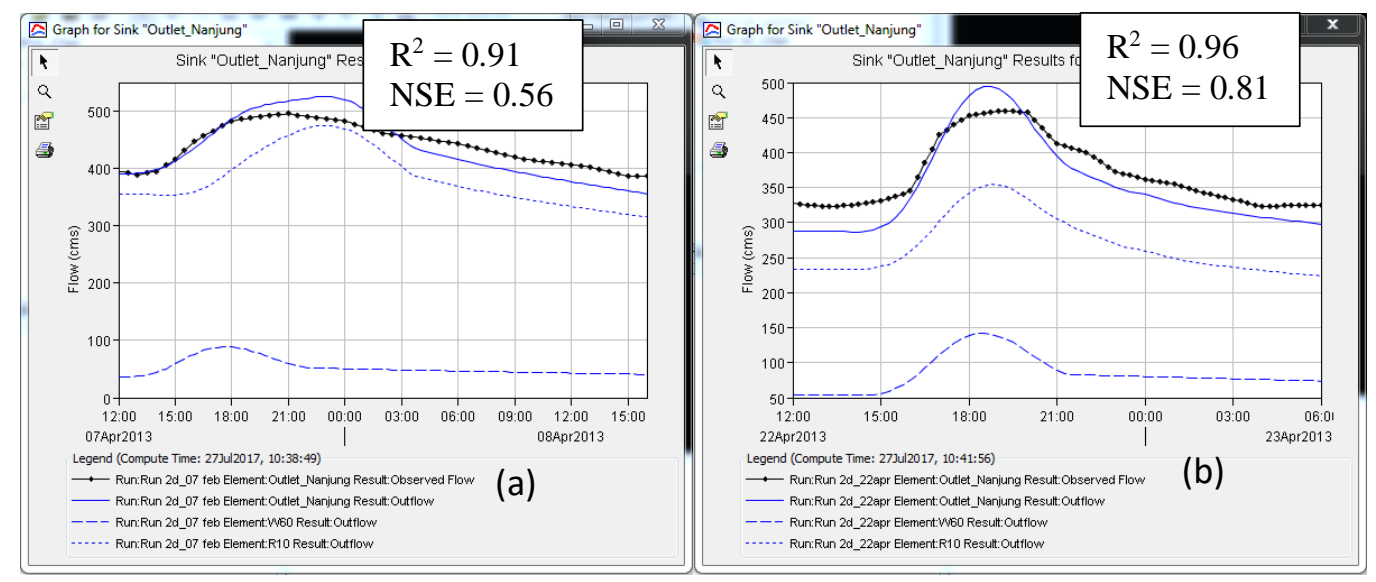

Gambar 2. Hidrograf hasil simulasi model dan observasi proses kalibrasi dengan NSE yang memuaskan (a) dan NSE sangat baik (b)
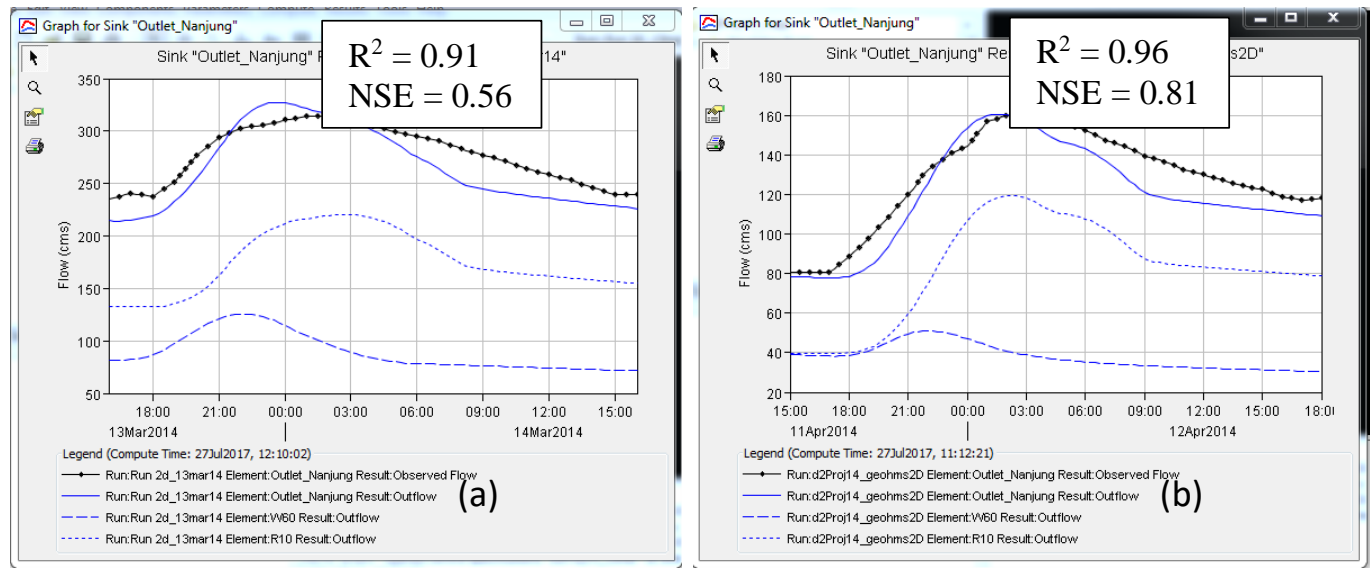

Gambar 3. Hidrograf hasil simulasi model dan observasi pada proses validasi dengan NSE memuaskan (a) dan NSE sangat baik (b) 


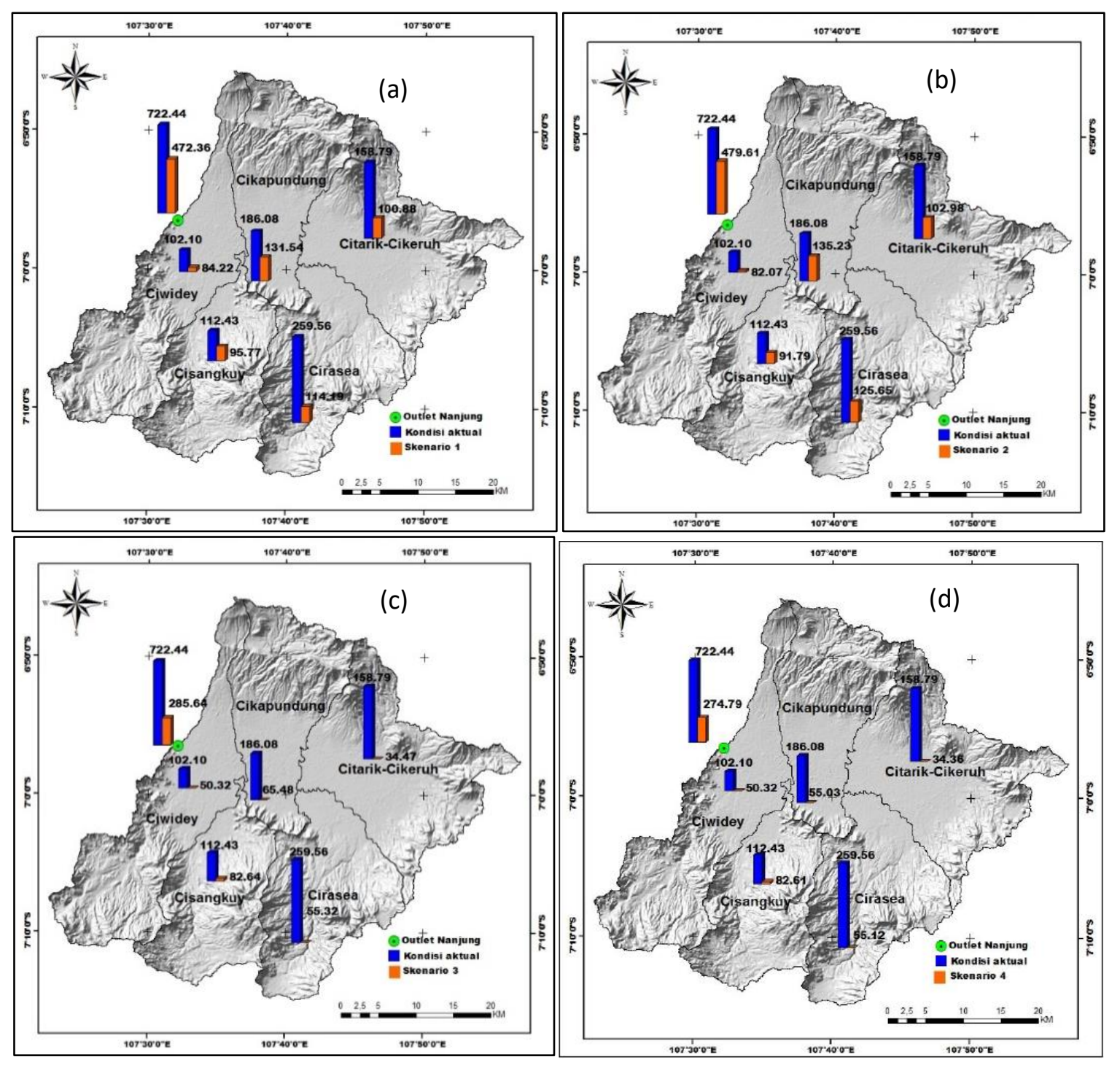

Gambar 4. Perbandingan debit puncak antara kondisi aktual dengan skenario 1 (a); skenario 2 (b); skenario 3 (c); dan skenario 4 (d).

Hasil simulasi model HEC-HMS menunjukkan bahwa seluruh skenario mampu menurunkan debit puncak pada masing-masing sub DAS maupun di outlet. Berdasarkan penerapan skenario 1 dapat menurunkan debit puncak di outlet sebesar $34.62 \%$ dari kondisi aktual. Penurunan debit puncak terbesar terdapat pada sub DAS Cirasea sebesar $145.37 \mathrm{~m}^{3}$ detik $^{-1}(56.01 \%)$. Kondisi ini disebabkan karena pada DAS Cirasea mengalami peningkatan Ia sebesar $69.06 \%$ dan penurunan bilangan kurva sebesar $6.38 \%$. Penurunan debit puncak terkecil terdapat pada sub DAS Cisangkuy sebesar $16.66 \mathrm{~m}^{3}$ detik $^{-1}(14.82 \%)$. Penerapan skenario 2 dapat menurunkan debit puncak di outlet sebesar dan $33.61 \%$ dari kondisi aktual. Sub DAS yang mengalami penurunan debit puncak terbesar dalam penerapan skenario 2 adalah sub DAS Cirasea sebesar $133.91 \mathrm{~m}^{3}$ detik $^{-1}$ (51.59\%) dan sub DAS yang mengalimi penurunan debit puncak terkecil dibandingkan dengan sub DAS yang lain adalah sub DAS Cisangkuy sebesar $20.03 \mathrm{~m}^{3}$ detik $^{-1}(18.36 \%)$.

Sementara penerapan skenario 3 dan 4 mampu menurunkan debit puncak di outlet bertutut-turut sebesar $60.46 \%$ dan $61.96 \%$ dari kondisi aktual. Hasil simulasi model HEC-HMS menunjukkan bahwa penerapan skenario 3, Penurunan debit puncak terkecil terdapat pada sub DAS Cisangkuy sebesar $29.79 \mathrm{~m}^{3}$ detik $^{-1}(26.50 \%)$ sementara sub
DAS yang mengalami penurunan debit puncak terbesar terdapat pada sub DAS Citarik-Cikeruh sebesar $204.24 \mathrm{~m}^{3}$ $\operatorname{detik}^{-1}(78.69 \%)$. penerapan skenario 4 mampu menurunkan debit puncak terkecil terjadi pada sub DAS Cisangkuy sebesar $29.82 \mathrm{~m}^{3}$ detik $^{-1}$ (26.52\%) sementara sub DAS yang mengalami penurunan debit puncak terbesar terdapat pada sub DAS Citarik-Cikeruh sebesar $124.43 \mathrm{~m}^{3}$ detik $^{-1}$ (78.36\%).

Besarnya penurunan debit puncak pada penerapan skenario 3 dan 4 disebabkan oleh meningkatnya luasan area serapan air oleh kegiatan reboisasi, penghijauan (agroforestry) dan sumur resapan pada skenario 3 dan 4 lebih tinggi sehingga lapisan kedap air (impervious) menurun sehingga dapat meningkatkan kemampuan retensi yang besar di wilayah hulu sehingga pada saat terjadinya hujan, air hujan tidak langsung berubah menjadi aliran permukaan dan membutuhkan waktu lebih panjang untuk mengalir ke outlet. Noordwijk et al. (2004) Tutupan lahan oleh pohon (baik secara penuh dalam bentuk hutan alam maupun tutupan sebagian seperti lahan pertanian/agroforestry) memiliki hubungan yang erat dengan fungsi hidrologi yaitu pada aspek total hasil air dan daya sangga DAS terhadap debit puncak pada berbagai skala waktu. 


\section{Time to Peak (Tp)}

Waktu menuju debit puncak (time to peak) merupakan waktu yang diperlukan pada masing-masing sub DAS untuk terjadinya debit puncak. Berdasarkan hasil analisis model HEC-HMS menunjukkan bahwa pada kondisi aktual nilai waktu menuju debit puncak (Tp) pada masingmasing sub DAS relatif sama yaitu berkisar antara 4.25-5.50 jam. Sub DAS Citarik-Cikeruh dan sub DAS Cikapundung memiliki Tp yang sama yaitu 4.25 jam serta Tp pada sub DAS Cirasea dan sub DAS Cisangkuy juga sama yaitu 4.75 jam. Kondisi tersebut sangat berbahaya apabila diatas sub DAS tersebut terjadi hujan secara bersamaan, karena dapat menyebabkan air terkonsentrasi pada outlet dalam waktu yang sama sehingga dapat melebihi daya tampung sungai utama dan dapat menyebabkan banjir. Perbandingan nilai time to peak antara kondisi aktual dengan skenario mitigasi banjir selengkapnya disajikan pada Gambar 5.

Berdasarkan hasil simulasi model HEC-HMS pada masing-masing skenario mitigasi banjir menunjukkan bahwa skenario 3 dan 4 merupakan skenario terbaik dalam meningkatkan $\mathrm{Tp}$ pada masing-masing sub DAS. Peningkatan time to peak pada masing-masing sub DAS sebesar 1.25-3.75 jam dari kondisi aktual. Sementara itu, penerapan skenario 1 dan 2 juga mampu meningkatkan Tp pada masing-masing sub DAS sebesar 0.5-1.0 jam.

\section{Volume Direct Runoff (DRO)}

Besarnya debit puncak berbanding lurus dengan besarnya volume direct runoff (DRO). Hasil simulasi model HEC-HMS menunjukkan bahwa masing-masing skenario mitigasi banjir mampu menurunkan volume direct runoff pada masing-masing sub DAS. Berdasarkan hasil simulasi model HEC-HMS diperoleh volume DRO pada kondisi aktual pada masing-masing sub DAS sebesar 776.68 $3,860.85 \times 10^{3} \mathrm{~m}^{3}$. Perbandingan volume direct runoff antara kondisi aktual dan beberapa skenario mitigasi banjir selengkapnya disajikan pada Tabel 3.

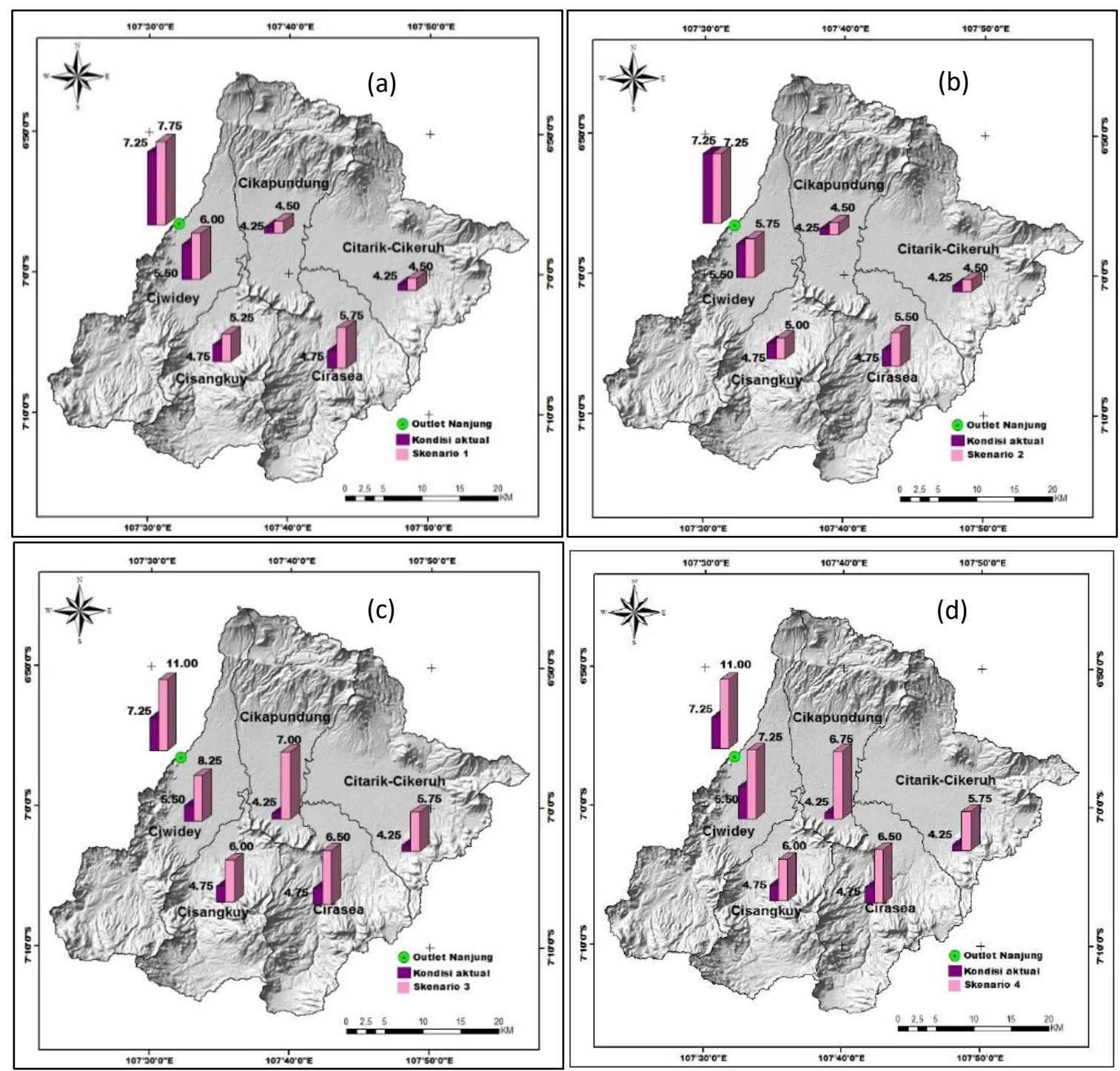

Gambar 5. Perbandingan nilai time to peak antara kondisi aktual dengan: skenario 1 (a); skenario 2 (b); skenario 3 (c); dan skenario 4 (d). 
Tabel 3. Perbandingan volume direct runoff kondisi aktual dengan beberapa skenario mitigasi banjir.

\begin{tabular}{|c|c|c|c|c|c|c|c|c|}
\hline \multirow{2}{*}{ Sub DAS } & \multicolumn{2}{|c|}{ Skenario 1} & \multicolumn{2}{|c|}{ Skenario 2} & \multicolumn{2}{|c|}{ Skenario 3} & \multicolumn{2}{|c|}{ Skenario 4} \\
\hline & VDRO & $\Delta(\%)$ & VDRO & $\Delta(\%)$ & VDRO & $\Delta(\%)$ & VDRO & $\Delta(\%)$ \\
\hline Ciwidey & $1,023.46$ & -13.52 & 971.47 & -17.91 & 557.11 & -52.93 & 555.42 & -53.07 \\
\hline Citarik-Cikeruh & $1,554.09$ & -29.53 & $1,569.48$ & -28.83 & 710.09 & -67.80 & 708.74 & -67.86 \\
\hline Cipadung & $1,558.96$ & -26.57 & $1,586.33$ & -25.28 & 802.01 & -62.22 & 554.67 & -73.87 \\
\hline Cirasea & $1,796.11$ & -53.48 & $1,973.68$ & -48.88 & 716.19 & -81.45 & 712.37 & -81.55 \\
\hline
\end{tabular}

Keterangan: VDRO adalah volume direct runoff $\left(10^{3} \mathrm{~m}^{3}\right)$

Hasil simulasi model HEC-HMS menunjukkan bahwa seluruh skenario mitigasi banjir mampu menurunkan volume direct runoff pada masing-masing sub DAS dibandingkan dengan kondisi aktual. Hasil simulasi skenario 1 menggunakan model HEC-HMS menunjukkan bahwa Penurunan volume DRO terbesar terjadi pada sub DAS Cirasea sebesar 2,064.74 $\mathrm{m}^{3}$ detik $^{-1}$ (53.48\%) dan penurunan volume DRO terkecil terjadi pada sub DAS Ciwidey sebesar $160.01 \mathrm{~m}^{3}$ detik $^{-1}$ (29.53\%). Sementara pada skenario 2, Penurunan volume DRO terbesar terdapat pada dua sub DAS yaitu sub DAS Cisangkuy mengalami penurunan volume DRO sebesar $326.05 \mathrm{~m}^{3}$ detik $^{-1}$ (41.98\%) dan sub DAS Cirasea mengalami penurunan volume DRO sebesar 1,887.17 $\mathrm{m}^{3}$ detik $^{-1}(48.88 \%)$. Adapun sub DAS yang mengalami penurunan volume DRO terkecil adalah sub DAS Ciwidey sebesar $212.00 \mathrm{~m}^{3} \operatorname{detik}^{-1}(17.91 \%)$.

Disisi lain pada penerapan skenario 3, Hasil simulasi model HEC-HMS menunjukkan bahwa penerapan skenario 3 mampu menurunkan volume DRO pada masing-masing sub DAS. Penurunan volume DRO yang terjadi sebanyak 462.133,144.66 $\mathrm{m}^{3}$ detik $^{-1}$ (52.93-81.45\%). Berbeda dengan penurunan Qp. penurunan volume DRO tertinggi terdapat pada sub DAS Cirasea sebanyak 3,144.66 $\mathrm{m}^{3}$ detik $^{-1}(81.45 \%)$ dan penurunan volume DRO terkecil terdapat pada sub DAS Ciwidey sebesar $626.36 \mathrm{~m}^{3}$ detik $^{-1}$ (52.93\%). Skenario 4 merupakan skenario terbaik dalam penurunan volume DRO. Hasil simulasi model HEC-HMS menunjukkan bahwa berbeda dengan penurunan $\mathrm{Qp}$, penurunan volume DRO tertinggi terjadi pada sub DAS Cirasea sebanyak $3,148.48 \mathrm{~m}^{3}$ detik $^{-1}(266.04 \%)$ dan penurunan volume DRO terkecil terdapat pada sub DAS Cisangkuy sebesar $462.77 \mathrm{~m}^{3}$ detik $^{-1}$ (39.10\%) kondisi tersebut disebabkan karena pada skenario 4 terjadi peningkatan luasan penggunaan lahan bervegetasi seperti hutan, agroforestry, lahan pertanian serta pembuatan rorak dan sumur resapan. Maryanto et al. (2014) Peningkatan tutupan lahan hutan, dan agroforestry menyebabkan peningkatan kapasitas infiltrasi tanah yang pada giliran menyebabkan penurunan aliran permukaan dan debit sungai serta dapat meningkatkan ketersediaan air pada bulan-bulan kering.

\section{Volume Debit Aliran}

Kondisi yang sama juga terjadi pada volume debit hasil simulasi model HEC-HMS. Berdasarkan analisis model diperoleh volume aliran dari masing-masing sub DAS sebesar 3,649.31-6,288.85 x $10^{3} \mathrm{~m}^{3}$ dan volume di outlet mencapai $18,313.28 \times 10^{3} \mathrm{~m}^{3}$. Dalam hal ini volume aliran tertinggi terdapat pada sub DAS Cirasea yaitu sebesar 6,288.85 x $10^{3}$ $\mathrm{m}^{3}$. Kondisi tersebut menunjukkan bahwa pada kejadian banjir tanggal 8 Januari 2013 (kondisi aktual) sub DAS Cirasea memberi sumbangan debit aliran terbesar pada sungai utama dibandingkan dengan sub DAS lainnya. Penurunan fungsi hidrologis di sub DAS Cirasea (wilayah hulu dari DAS Citarum Hulu) tidak dapat disebabkan oleh faktor pengunaan lahan. Dalam hal ini penggunaan lahan. Menurut Indarto (2016) bahwa faktor fisik yang berpengaruh terhadap aliran permukaan adalah luas dan bentuk DAS, kerapatan jaringan sungai, kemiringan DAS, faktor tanah dan penggunaan lahan. Perbandingan volume debit aliran kondisi aktual dengan beberapa skenario mitigasi banjir secara spasial selengkapnya disajikan pada Tabel 4.

Hasil simulasi model HEC-HMS menunjukkan bahwa penerapan skenario 1 mampu menurunkan volume aliran di outlet sebesar 4,847.38 $\mathrm{m}^{3}$ detik $^{-1}(26.47 \%)$. Sub DAS yang mengalami penurunan volume aliran terbesar terdapat dapat sub DAS Cirasea sebesar 3,238.2 $\mathrm{m}^{3}$ detik $^{-1}(51.50 \%)$ dan penurunan volume aliran terkecil terdapat pada sub DAS Ciwidey sebesar $231.68 \mathrm{~m}^{3}$ detik $^{-1}$ (12.61\%). Penerapan skenario 2 dapat menurunkan volume aliran di masing-masing sub DAS maupun di outlet. volume aliran di outlet menurun sebesar 4,714.01 m $\mathrm{m}^{3} \operatorname{detik}^{-1}$ (25.74\%). Sub DAS yang mengalami penurunan volume aliran terbesar terjadi pada sub DAS Cirasea sebesar 2,990.06 $\mathrm{m}^{3}$ detik $^{-1}(47.55 \%)$ dan sub DAS yang mengalami penuruna volume aliran terkecil terjadi pada sub DAS Cisangkuy sebesar $326.05 \mathrm{~m}^{3}$ detik $^{-1}(8.57 \%)$.

Disisi lain, berdasarkan hasil simulasi model HECHMS, penerapan skenario 3 menunjukkan terjadi penurunan volume aliran di outlet menurun sebesar $9,456.4 \mathrm{~m}^{3}$ detik $^{-1}$ $(48.36 \%)$. Sub DAS yang mengalami penurunan volume aliran terbesar adalah sub DAS Cikeruh-Citarik sebesar $4,526.57 \mathrm{~m}^{3}$ $\operatorname{detik}^{-1}(71.98 \%)$. Penurunan volume aliran terkecil berdasarkan simulasi model HEC-HMS terjadi pada sub DAS Cisangkuy sebesar $462.3 \mathrm{~m}^{3}$ detik $^{-1}(12.15 \%)$. Hasil simulasi skenario 4 menunjukkan bahwa skenario ini mampu menurunkan volume debit aliran terjadi penurunan volume aliran di outlet menurun sebesar $8,856.88 \mathrm{~m}^{3} \operatorname{detik}^{-1}(48.36 \%)$. Sub DAS yang mengalami penurunan volume aliran terbesar adalah sub DAS Cikeruh-Citarik sebesar $4,530.52 \mathrm{~m}^{3} \operatorname{detik}^{-1}$ (72.04\%). Penurunan volume aliran terkecil berdasarkan simulasi model HEC-HMS terjadi pada sub DAS Cisangkuy sebesar $462.13 \mathrm{~m}^{3}$ $\operatorname{detik}^{-1}(12.17 \%)$. Penurunan tersebut disebabkan karena pengembalian fungsi hutan di wilayah hulu sehingga wilayah serapan air meningkat dan pada saat terjadi hujan extrim, air hujan yang jatuh langsung terserap oleh tanah dan aliran permukaan yang terjadi tidak terlalu besar. 
Tabel 4. Perbandingan volume debit aliran kondisi aktual dengan beberapa skenario mitigasi banjir.

\begin{tabular}{lcrrrrrrr}
\hline \multirow{2}{*}{ Sub DAS } & \multicolumn{2}{c}{ Skenario 1} & \multicolumn{2}{c}{ Skenario 2} & \multicolumn{2}{c}{ Skenario 3 } & \multicolumn{2}{c}{ Skenario 4 } \\
\cline { 2 - 10 } & \multicolumn{1}{c}{ VDA } & \multicolumn{1}{c}{$\Delta(\%)$} & \multicolumn{1}{c}{ VDA } & \multicolumn{1}{c}{$\Delta(\%)$} & \multicolumn{1}{c}{ VDA } & \multicolumn{1}{c}{$\Delta(\%)$} & \multicolumn{1}{c}{ VDA } & $\Delta(\%)$ \\
\hline Ciwidey & $2,277.72$ & -13.52 & $2,225.76$ & -14.60 & $1,692.43$ & -35.06 & $1,690.74$ & -35.13 \\
Cisangkuy & $3,571.46$ & -6.09 & $3,477.09$ & -8.57 & $3,341.01$ & -12.15 & $3,340.37$ & -12.17 \\
Citarik-Cikeruh & $2,357.09$ & -35.41 & $2,400.89$ & -34.21 &, 853.58 & -76.61 & 850.99 & -76.68 \\
Cipadung & $3,476.76$ & -25.48 & $3,551.93$ & -23.87 & $2,186.74$ & -53.13 & $1,939.40$ & -58.43 \\
Cirasea & $3,050.03$ & -51.50 & $3,298.79$ & -47.55 & $1,762.28$ & -71.98 & $1,758.33$ & -72.04 \\
Outlet & $1,3465.9$ & -26.47 & $13,599.27$ & -25.74 & $9,456.40$ & -48.36 & $9,233.82$ & -49.58 \\
\hline
\end{tabular}

Keterangan: VDA = volume debit aliran

\section{Rekomendasi Skenario Mitigasi Banjir}

Hasil simulasi model HEC-HMS menunjukkan bahwa skenario 4 secara keseluruhan dapat memperbaiki karakteristik hidrologi di masing-masing sub DAS dan di outlet. Penerapan skenario 4 di outlet dapat menurunan debit puncaksebesar $447.65 \mathrm{~m}^{3}$ detik $^{-1}(61.96 \%)$, meningkatkan waktu menuju debit puncak selama 3.75 jam (51.72\%), dan menurunkan volume aliran sebesar 9,079.46 $\mathrm{m}^{3}$ detik $^{-1}$ (49.58\%). Penerapan skenario 1 hanya mampu menurunkan debit puncak di outlet sebesar $34.62 \mathrm{~m}^{3}$ detik $^{-1}$ dan hanya sub DAS Cirasea saja yang menunjukkan perubahan yang signifikan terhadap perbaikan karakteristik hidrologinya.

Disisi lain realisasi untuk skenario 1 memerlukan waktu yang lama karena saat ini penerapan skenario 1 masih belum dijalankan secara keseluruhan sesuai dengan arahan yang tercantum pada RTRWP Jawa Barat dan Perda No. 22 Tahun 20 tentang Rencana Tata Ruang Wilayah Provinsi Jawa Barat yang telah ditetapkan. Sementara itu untuk penerapan skenario 2 hanya mampu menurunkan debitpuncak di outlet sebesar $33.61 \%$ dan penerapan RTk-RHL saat ini hanya difokuskan pada wilayah hulu saja dari masing-masing sub DAS. Dengan demikian penerapan skenario 2 tidak dapat mencakup keseluruhan wilayah DAS.

Adapun untuk penerapan skenario 3 juga dapat menurunkan debit puncak di outlet sebesar $60.46 \%$ namun kendala utama penerapan untuk penerapan skenario ini adalah pada biaya pelaksanaan pembangunan bangunan pengendali aliran permukaan. Berdasarkan pertimbangan diatas, maka rekomendasi yang dipilih dalam upaya mitigasi penurunan debit banjir untuk daerah penelitian adalah menerapkan seluruh skenario mitigasi yang telah dibahas di atas. Hal ini disarankan karena hasilnya dapat memberikan angka penurunan ancaman banjir yang baik pada seluruh sub DAS. Dengan kata lain dari rekomendasi ini diharapkan dapat memberikan hasil berupa penurunan jumlah aliran permukaan yang lebih optimal di seluruh sub DAS.

\section{SIMPULAN}

Model HEC-HMS memiliki performa yang baik dalam memprediksi debit puncak banjir dengan nilai $\mathrm{R}^{2}$ antara 0.81-0.96 dan nilai NSE sebesar 0.56-0.87.

Debit puncak banjir (peak discharge) dalam periode penelitian diwakili pada kejadian banjir tanggal 8 Januari 2013 yaitu debit puncak di outlet sebesar 722.44 $\mathrm{m}^{3}$ detik $^{-1}$, waktu puncak debit (time to peak) di outlet selama 7.25 jam, volume debit aliran sebesar18,313.28 x $10^{3} \mathrm{~m}^{3}$.
Penerapan skenario mitigasi banjir 4 merupakan skenario mitigasi banjir terbaik dibandingkan dengan 3 skenario mitigasi banjir lainnya karena mampu menurunkan debit puncak sebesar $447.65 \mathrm{~m}^{3}$ detik $^{-1}$ (61.96\%), meningkatkan time to peak sebesar 3.75 jam $(51.72 \%)$ dan menurunkan volume aliran sebesar 9,079.46 x $10^{3} \mathrm{~m}^{3}(49.58 \%)$.

\section{DAFTAR PUSTAKA}

[BPLHD] Badan Pengelolaan Lingkungan Hidup. 2013. Rencana Aksi Mitigasi dan Adaptasi Perubahan Iklim Dalam Kerangka Pengelolaan Sumberdaya Air DAS Citarum di Kota Bandung. BPLH, Bandung.

[USACE] United State Army Corps of Engineering Hydrologic Engineering Center. 2012. Hydrologic Modeling System HEC-HMS-User Manual. US Army Corps of Engineers Institute for Water Resources Hydrologic Engineering Center, Davis (USA).

Affandy, N.A. dan N. Anwar. 2008. Pemodelan hujan-debit menggunakan model HEC-HMS di DAS Sampean Baru [Tesis]. Institut Teknologi Surabaya. Surabaya.

Choudhari, K., B. Panigrahi and J.C. Paul. 2014. Simulation of rainfall-runoff process using HEC-HMS model for Balijore Nala watershed, Odisha, India. International Journal of Geomatic and Geoscience, 5(2):253-265.

Gokgoz, T.N., N. Ulugtekin, M. Basaraner and F. Gulgen. 2006. Watershed delineation from grid DEMs in GIS: effects of drainage lines and resolution. $10^{\text {th }}$ Int. Specialised Conference on Diffuse Pollution and Sustainable Basin Managemen. 18-22 September 2006 Istanbul-Turkey.

Indarto. 2012. Hidrologi Dasar Teori dan Contoh Aplikasi Model Hidrologi. Bumi Aksara, Jakarta.

Indarto. 2016. Hidrologi: Metode Analisis dan Tool untuk Interpretasi Hidrograf Aliran Sungai. Bumi Aksara, Jakarta.

Kirpich, Z.P. 1940. Time of concentration of small agricultural watersheds. Civil Engineering Journal, 10(6):362-371.

Maryanto, A., K. Murtilaksono dan L.M. Rachman. 2014. Perencanaan pembangunan lahan dan pengaruhnya terhadap sumberdaya air di DAS Way Besai-Lampung. Jurnal Penelitian Kehutanan Wallacea, 3:85-95.

Moriasi, D.N., J.G. Arnold, M.W.V. Liew, R.L. Bingner, R.D. Harmel and T.L. Veith. 2007. Model evaluation 
guidelines for systematic quantification of accuracy in watershed simulation. American Society of Agricultural and Biological Engineers, 50:885-900.

Noordwijk, M.V., F. Agus, D. Suprayogo, K. Hairiah, B. Pasya, B. Verbist dan Farida. 2004. Peranan agroforestri dalam mempertahankan fungsi hidrologi daerah aliran sungai (DAS). AGRIVITA, 26:1-8.

Putiamini, S. 2014. Pemodelan spasial kejadian banjir daerah aliran sungai Ciliwung Hulu [Tesis]. Universitas Indonesia. Depok.
Sitanggang, G.E., I. Suprayogi dan Trimaijon. 2014. Pemodelan hujan debit pada sub daerah aliran sungai menggunakan program bantu HEC-HMS (Studi kasus pada Kanal Duri). Jurnal Online Mahasiswa Fakultas Teknik Universitas Riau, 1:1-14

[SK] Surat Keputusan Menteri Kehutanan Republik Indonesia Nomor SK. 328/Menhut-II/2009. 2009. Penetapan Daerah Aliran Sungai Prioritas dalam Rangka Rencana Pembangunan Jangka Menengah (RPJM) Tahun 20102014. Kementerian Kehutanan. 